Peter Guardino. The Dead March. A History of the MexicanAmerican War. Cambridge y Londres: Harvard University Press, 2017, 502 p. ISBN 9780674972346

\title{
Claudia Guarisco
}

claudia.guarisco@hotmail.com

The Dead March es un libro de historia social y cultural sobre la sobre todo en las experiencias de soldados, así como en la población civil mexicana expuesta a la violencia del ejército estadounidense. En esta nueva historia militar del conflicto, como algunos podrían llamarla, Guardino busca captar el sentido de la praxis atendiendo no solamente a los aspectos estructurales de la sociedad sino también a la cultura. Del amplio espectro de valores, creencias y aspiraciones de la época, Guardino recoge los más evidentes, agrupándolos bajo las categorías de género, raza y religiosidad. Por género alude, básicamente, a los modelos de comportamiento masculino. Por raza, a los discursos sobre los fenotipos humanos; $\mathrm{y}$ por religiosidad, al conjunto de creencias relacionadas con el más allá. En términos de procedimiento, Guardino combina espléndidamente la interpretación con la explicación cuasi causal o correlacional, si se quiere. Es esta ontología social tan completa, juntamente con el dinamismo del método, lo que dota de profundidad y originalidad al trabajo, distinguiéndolo de las muchas y muy buenas obras que se han publicado sobre el tema a lo largo de varias décadas. Las fuentes utilizadas por el autor incluyen, precisamente, esta vasta producción historiográfica sobre la guerra México-Estados Unidos, además de documentación oficial, así como diarios, cartas y memorias generadas tanto por miembros del ejército estadounidense como mexicano.

De estilo ágil, claro y entretenido, los nueve capítulos de The Dead March transcurren a lo largo de una cronología tradicional de la guerra, presentando estructuras, luchas internas de gobierno y detalladas descripciones de tácticas de guerra, campañas y batallas. Sin embargo, esto no es todo. La novedad de la aproximación de Guardino radica en situar en el centro de esos diferentes escenarios a los soldados, dando 
cuenta de los constreńimientos que los contextos nacionales impusieron a sus prácticas y, sobre todo, de los sentidos provistos por sus universos culturales. En el primer capítulo, Guardino presenta la rebelión de Texas como el detonante del conflicto. Considera el levantamiento que tuvo lugar en los años treinta del siglo XIX como la respuesta de los habitantes de ese estado a la política centralista de México, que consideraban vulneraba su autonomía y, con ello, la posibilidad de prosperar gracias a la proximidad de los Estados Unidos. Texas se mantuvo en rebeldía hasta 1845 , año en el que el presidente estadounidense James Polk no solamente anexó el territorio y demandó que el gobierno de México lo reconociera como parte de Estados Unidos, señalando el río Bravo (río Grande) como punto limítrofe entre las dos naciones. Polk, además, exigió de México la venta de grandes porciones de su territorio del norte, particularmente California y Nuevo México. Como símbolo del poder estadounidense, Polk envió fuerzas regulares al mando del general Zachary Taylor a Corpus Christi, en la desembocadura del río Bravo. Guardino caracteriza a los soldados de Taylor como no ciudadanos. Se trataba de trabajadores de las ciudades quienes entonces experimentaban inseguridad laboral y una creciente dependencia del trabajo asalariado. Cerca de la mitad del ejército regular estaba compuesto por inmigrantes irlandeses, alemanes e ingleses, que habían llegado al país del norte en las décadas de los veinte y treinta. Eran católicos y, por ello, estigmatizados por buena parte de las clases medias y altas ligadas al partido demócrata; nativismo, éste, heredado de la reforma protestante. Además, los soldados regulares eran considerados seres serviles que, al igual que esclavos y animales, estaban sometidos a los castigos físicos que eran pan de cada día en sus unidades. Con todo, el ejército regular fue la mejor opción disponible, a mediados de la década de los cuarenta, para migrantes y no migrantes pobres. Esto, porque la paga era constante y, además, se les proveía de comida y vestido. $\mathrm{Al}$ ingresar al ejército, migrantes y no migrantes adoptaron nuevos elementos culturales. Entre ellos destacaron los valores de la fuerza y resistencia física, la rudeza y agresividad, así como la camaradería. En contraste, los oficiales eran profesionales de la guerra que provenían de clases medias y altas, y que habían seguido la carrera militar en la prestigiosa academia de West Point. Estos, no solamente eran expertos en las artes 
de la guerra y en su enseñanza, sino también autoritarios y severos con sus subordinados.

En respuesta a la ocupación estadounidense, el gobierno mexicano envió a su propio ejército regular, milicia activa o ejército no ciudadano a Matamoros. Estas fuerzas se componían de unidades organizadas de acuerdo a los pueblos, villas y ciudades de los cuales los soldados provenían. A diferencia de lo que sucedía con los regulares del norte, el ejército mexicano no era atractivo para los pobres, ya que sus gobernantes no podían pagar sus exiguos salarios, alimentarlos ni vestirlos de manera sostenida. De ahí que los políticos decidieran asignar a cada estado una cuota de reclutas que estuvieran en servicio durante seis ańos consecutivos. Los funcionarios municipales que se hicieron cargo de la leva tendieron a retener a los elementos útiles para la sociedad local. Es decir: hombres alfabetos, profesionales, comerciantes, empresarios agrícolas y campesinos con familia. En su lugar, llenaron los cupos principalmente con vagos y reos culpables de crímenes serios, como asalto, violación, robo y posesión ilegal de armas. El único incentivo que muchos de estos hombres vieron en el ejército regular fue el de poder llevar consigo a sus esposas (soldaderas) e, incluso hijos, compartiendo con ellos sus míseras raciones y pagas. A diferencia de los soldados, los oficiales del ejército regular provenían de clases acomodadas y se habían graduado en la Academia Militar de México, o bien habían sido colocados en puestos de mando gracias a conexiones familiares y políticas.

En el capítulo dos, Guardino da cuenta de los esfuerzos puestos por el gobierno estadounidense en la organización de un ejército de voluntarios de cerca de cincuenta mil hombres. La principal diferencia entre regulares y voluntarios es que los últimos eran verdaderos ciudadanossoldados, provenientes de los estados del sur y de las áreas sureñas de los estados del Medio Oeste. Eran jóvenes que pertenecían a familias acomodadas, que sabían leer y escribir, y que tenían sólidas raíces en sus comunidades de origen. Respondían a un modelo de masculinidad "racializada", que situaba a los hombres blancos en la cúspide de la jerarquía social, dejando en la base a los miembros de otras razas y a las mujeres. Ese referente de género coexistía con valores nativistas y con la creencia del destino manifiesto de la democracia jacksoniana. El destino manifiesto afirmaba la inevitabilidad de la propagación de la liber- 
tad y de la democracia estadounidense. De ahí que los voluntarios vieran a los mexicanos como seres racialmente inferiores; descendientes de indios y católicos "ignorantes" y "supersticiosos", y consideraran legítima la anexión de sus territorios. Por otro lado, la camaradería era un valor particularmente fuerte entre los soldados, el cual emergía de solidaridades territoriales preexistentes. Asimismo, compartían una noción de justicia que no siempre iba de la mano de las instituciones judiciales. Este vigilantismo no solamente justificaba la violencia hacia el "otro" mexicano, sino que promovía la complicidad entre camaradas. Todos estos referentes, aunados al hecho de que los oficiales eran elegidos por sus propios hombres y a que ejercían una autoridad paternalista, permitió que los voluntarios se ausentaran, repetidamente y sin autorización de sus superiores, de las ciudades y campos en los que se acuartelaban, con el fin de atacar, robar, matar y violar a civiles mexicanos.

En el capítulo tres, el autor explica cómo, siguiendo la gramática cultural de la violencia ejemplar que había nacido de sus enfrentamientos con los comanches, los pocos mexicanos que existían en el área invadida se organizaron en unidades guerrilleras, atacando con violencia a los voluntarios. Éstos, no solamente respondieron de la misma manera, sino que, además, mutilaron y ejecutaron a hombres, mujeres y nińos inocentes. Por otro lado, Guardino muestra a un general Antonio López de Santa Anna abocado, luego de las derrotas de Palo Alto, Resaca de Palma y Monterrey, a organizar un formidable ejército en San Luis Potosí, entre octubre de 1846 y enero de 1847. Gracias a su talento para convencer y al apoyo tanto de la sociedad potosina como de los estados vecinos, Santa Anna pudo armar, entrenar, vestir y alimentar a casi veinte mil hombres destinados a enfrentar a los voluntarios del norte. En sus marchas hacia los campos de batalla, sin embargo, muchos desertaron, enfermaron o murieron debido a la escasez de agua, comida y al frío intenso de ese invierno.

En los capítulos cuarto y quinto, Guardino aborda el tema de las campañas de Veracruz y de la Ciudad de México. Con el fin de tomar la capital, el gobierno estadounidense aumentó sus fuerzas de voluntarios con hombres provenientes de sectores urbanos pobres, a cambio de salarios más altos y tierras. Por su parte, Santa Anna estuvo a cargo no solamente de las fuerzas regulares, sino de las unidades de la Guardia 
Nacional recientemente creadas en el valle de México, Puebla, Veracruz, Michoacán, Oaxaca y Guerrero. El retorno del federalismo en 1846 había traído consigo la revitalización del ideal del ciudadanosoldado de la tradición miliciana de finales del siglo xvıII e inicios del XIX, corporeizándose en fuerzas regulares compuestas de hombres de muy variados orígenes sociales e inclinaciones políticas. Por ejemplo, los nacionales de Oaxaca y Guerrero eran campesinos que, en muchos casos, no hablaban español. La Guardia de Guerrero estaba compuesta sobre todo por mulatos e indígenas que habían desarrollado una versión popular del federalismo con énfasis en impuestos bajos, autonomía local y oposición a la explotación extranjera. Los nacionales indígenas de Oaxaca, si bien poseían un pasado de autonomía local, mantenían un fuerte compromiso fiscal con el gobierno, la religión los mantenía unidos a mestizos y criollos, y simpatizaban con conservadores y centralistas. La Guardia Nacional de Michoacán, en cambio, estaba compuesta de morelianos mestizos de clase media; artesanos y jóvenes de familias distinguidas. Los nacionales, al igual que los regulares, debieron enfrentar el problema de las pagas intermitentes y, muchas veces, el abandono, y consecuentes penurias, de sus padres, esposas e hijos. Estas similitudes no impidieron, sin embargo, que los miembros de las nuevas fuerzas se vieran a sí mismos como superiores respecto de los regulares. Esto, porque no habían sido reclutados de manera coactiva ni estaban sujetos a castigo corporal alguno. En conjunto, nacionales y regulares conformaron un ejército de cerca de veinte mil hombres bajo la dirección de Santa Anna, incluidas las secciones ligeras de la Guardia Nacional, que no eran otra cosa sino unidades guerrilleras comandadas por hombres de campo con el prestigio y la riqueza para formarlas, armarlas, vestirlas y alimentarlas. Durante el verano y el otońo de 1847 , las guerrillas fueron muy activas en la ruta de Veracruz hacia la Sierra Central.

En los capítulos séptimo, octavo y noveno, Guardino da cuenta de la caída de la Ciudad de México y de la resistencia tanto del ejército como de léperos, sastres, carpinteros, vendedores de lotería y clérigos, entre otros. Asimismo, documenta las operaciones contrainsurgentes de las fuerzas estadounidenses que, en su afán de acabar con los guerrilleros que operaban en el valle de México y en los alrededores de Pue- 
bla, incurrieron en una serie de atrocidades en contra de la población civil. El autor también reflexiona acerca de los eventos que rodearon la firma del tratado Guadalupe Hidalgo, el cual selló la pérdida definitiva de Texas, los estados actuales de California, Arizona, Nevada, Utah y Nuevo México, y partes de Colorado, Wyoming y Oklahoma. Finalmente, Guardino se ocupa de la resistencia a la anexión por parte de los mexicanos de California y Nuevo México, de las "margaritas" o mujeres ligadas afectivamente a los invasores, así como de las dificultades enfrentadas por los soldados estadounidenses al momento de demandar las tierras prometidas por el gobierno a cambio de los servicios prestados en la guerra contra México.

La conclusión más importante de The Dead March es que la derrota de México en la guerra con Estados Unidos no se debió a la división y falta de compromiso de los mexicanos, como reza la tesis más generalizada sobre el tema. Por el contrario, sostiene el autor, los mexicanos enfrentaron con dignididad la agresión de los vecinos del norte. Ciertamente, los conflictos políticos internos obstruyeron esos esfuerzos, a veces de manera muy seria, pero fue, sobre todo, la prosperidad estadounidense y la relativa solidez de su estado lo que más incidió en la desmembración de México. Prosperidad y solidez expresadas en una fiscalidad eficiente que hizo posible pagar, vestir, alimentar y dotar de buen armamento a los miembros de los ejércitos regular y de voluntarios. La economía lo permitía. Estados Unidos era un país rico, con gran demanda de algodón por parte de los mercados europeos y de productos agrícolas, por los caribeños. En México, por el contrario, la precariedad de la economía y la ineficiencia de la recaudación fiscal hacían difícil, incluso, llevar a cabo las operaciones rutinarias del gobierno. De ahí la pobreza, hambruna y padecimientos de sus mal equipados soldados.

En cuanto a los orígenes de la guerra, Guardino coincide con la tendencia historiográfica que los sitúa en el expansionismo de la política jacksoniana. Además, señala la posición geográfica de los territorios del norte mexicano y la débil relación que mantenían con la economía del centro de México como un incentivo más para que los estadounidenses dieran inicio al conflicto. California y Nuevo México estaban profundamente ligados a la economía en expansión de los Estados Unidos. Disponían de ríos, mares y canales para desplazar productos desde California y 
Nuevo México hacia el sur y el este de ese país. Los puertos de California estaban más relacionados a los desembarcaderos de la costa este del país del norte que a los mexicanos. No sólo representaban buenos mercados para la ganadería y agricultura de California, sino que permitían abaratar los costos de trasporte. En el caso de Nuevo México, y aunque Saint Louis se encontraba bastante lejos de Santa Fe, el Santa Fe Trail ofrecía a los comerciantes un camino plano la mayor parte del tiempo, con agua y forraje para los animales que transportaban las manufacturas baratas que los novo mexicanos adquirían con el dinero obtenido de la venta de ovejas, textiles de lana y productos agrícolas en Chihuahua.

Por otro lado, The Dead March revisa una serie de debates presentes en la historiografía sobre la guerra. Por ejemplo: la Rebelión de los Polkos, en 1847. Guardino considera que ese enfrentamiento entre los miembros de la Guardia Nacional de la Ciudad de México no fue solamente un esfuerzo por impedir que el gobierno usara la riqueza de la Iglesia católica. Sostiene, además, que se trató de una confrontación en torno a las implicaciones sociales del republicanismo. El autor también discute la supuesta traición de Santa Anna, alegando sus grandes dotes de organizador y político y sus pocas cualidades de estratego. Asimismo, señala que si bien las guerrillas mexicanas causaron muchas bajas en las filas estadounidenses, también resultaron costosas para la sociedad mexicana. Finalmente, desarrolla el tema del nacionalismo mexicano, considerándolo como una expresión de la cultura con orígenes en la Guerra de Independencia.

Sostiene el autor de The Dead March que la identificación con México entre soldados y miembros de sociedad civil fue bien notoria en la época, incluso para los estadounidenses. Ulysses Grant, quien entonces era un joven oficial, admiraba su resistencia y movilidad; su habilidad para marchar largas distancias con poca comida y agua. Asimismo, viajeros de la época escribieron sobre el virulento nacionalismo popular de los pobres de México. Ciertamente, soldados, sastres, léperos y mulatos, entre otros, tuvieron motivos personales para luchar: coerción, miedo de perder sus vidas y las de sus seres queridos, así como la esperanza de contar con futuras ventajas sociales y políticas. Ninguno de estos intereses individuales, sin embargo, es incompatible con el imaginario de un México soberano. Este, ciertamente, se manifestó a lo 
largo de diferentes situaciones, con diferentes intensidades e involucrando a diferentes actores. Aunque no lo menciona expresamente, el libro de Guardino permite inferir que ese nacionalismo fue en parte producto del gobierno y, en parte, producto de la sociedad. Lo que hizo el gobierno fue crear un discurso más o menos coherente a partir de las ansiedades de la población y sus convicciones en torno a la familia, el catolicismo y la libertad, básicamente, difundiéndolo a través de panfletos, periódicos, documentos oficiales y otros compuestos por diferentes grupos políticos.

Desde mi punto de vista, The Dead March no tiene nada que criticar. No queda sino elogiar el enorme esfuerzo del autor y la inteligencia con la que ha sabido resolver las dificultades que una historia desde abajo y desde una doble perspectiva -la estadounidense y mexicanaimponen a su elaboración. Tal vez mencionar solamente la necesidad de seguir trabajando en dirección de la articulación entre conceptos, método y hechos históricos, porque es eso, precisamente, lo que permite el progreso de la ciencia histórica, independientemente del descubrimiento de nuevas fuentes. Esta reflexión me remite a la crítica que hace la historia de las ideas e instituciones políticas a la historia social y cultural, y que tiene que ver con mi propio trabajo sobre el nacionalismo en la Independencia de México. Existe la opinión bastante extendida de que el uso del término de nacionalismo mexicano a lo largo de la primera mitad del siglo xIx constituye un anacronismo. Esto, porque el discurso acerca de una identidad más allá del pueblo y de la región no constituía un todo sistemático, dotado de fundamentos filosóficos, ni producido exclusivamente por una elite educada. Tampoco contaba con instituciones que expresaran ese sentido de pertenencia y que, al mismo tiempo, promovieran la integración de la sociedad. Finalmente, no existen fuentes que citen el término "nacionalismo" y lo describan ampliamente. Es, sin embargo, la objeción en sí misma la que me parece anacrónica. La crítica proviene de una definición general de nacionalismo que tiene que ver más con el siglo XX que con el XIx. Ningún nacionalismo nació adulto y, en el caso de México, sus primeras expresiones se sitúan, precisamente, a lo largo de la primera mitad del XIX, como bien señalara Benedict Anderson en Comunidades imaginadas. Expresiones nacionalistas, por añadidura, al lado de un estado apenas 
en construcción y de una nación ausente. Como parte de la cultura, difícilmente se accede a los contenidos de los tempranos nacionalismos de manera directa. Antes que en discursos, éstos están en la praxis. Es labor del historiador decodificarla. El esfuerzo no es gratuito si se recuerda que los conceptos - aún los implícitos y generales- son esenciales para articular la historia social y cultural. Un franco debate en torno a estos puntos sería deseable. 